\title{
ゴムのダメージモデルの数值計算手法
}

\author{
石川覚志*1・永田孝 弘*2
}

\section{Numerical Solution Methods for the Elastometric Damage Model}

Satoshi ISHIKAWA*1, Takahiro NAGATA*2 ${ }^{* 1}$; Mechanical Design \& Analysis Corporation, Nagoya Office, Nishiki Chuo Building 8F, 3-5-7 Nishiki, Naka-ku, Nagoya 460-0003, Japan, *2; Mechanical Design \& Analysis Corporation, AXIS Chofu 2F, 1-40-2 Fuda, Chofu, Tokyo 182-0024, Japan)

Many rubber-like materials consist of a cross-linked elastomers substance with a distribution of small carbon particles as fillers. A piece of filler loaded rubber subjected to a series of loadings typically displays pronounced stress softening associated with damage. This stress softening phenomenon is referred to as the Mullins effect. The effects of strain history on the stresses and the formulation of constitutive models for filled and unfilled elastomers have been a particular focus of attention during the last few years. In this general remark, some representative damage functions are compared and two examples of permanent set are showed with maximal use of user-subroutine.

Key Words : Mullins Effect, Stress Softening, Pseudo Elastic Model, Permanent Set

\section{1. 緒言}

ゴム材料に対して引張側もしくは圧縮側に繰り返し負荷 を与えた場合，いわゆるMullins効果といわれるダメージ の影響が見られる.

ヒステリシスを伴うダメージの要因となる主要なメカニ ズムは以下のように整理できる。

- 応力軟化

- 内部摩擦

・ひずみに誘起される結晶化現象

- 構造的な破壊

- 領域変形の影響

この物理現象を有限要素法で取り扱うには，超弾性体の 構成則を負荷時と除荷時で異なる則を使用することで表現 できる。これまでに様々な研究者による定式化が考案され ている. 本稿ではMullins 効果に関するモデル化とその数

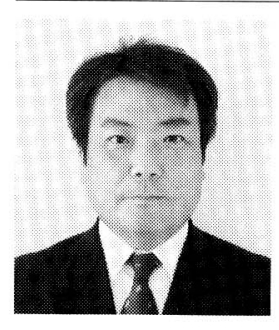

*11秼)メカニカルデザイン名古屋支社（４４600003 名古屋市中区錦 3-5-27錦中央ビル 8 階)名古屋支社長. 1992 年日本マーク侏入社, 1999年合併吸収によりエムエスシーソフト ウウェア侏勤務, 2006年 4 月より現職, 現在 に至る. 専門分野は非線形構造解析. 日本 ゴム協会, 日本材料学会, 日本機械学会会 員.
值計算手法の分野における各種ダメージ関数とその違いに ついて説明する. なお, 現行の汎用有限要素法コードでは 扱いきれない超弾性体の永久ひずみをユーザーサブルーチ ンで取り扱った事例を示す.

\section{Simo' ${ }^{1)}$ によるダメージモデル}

Simoは本来 (ダメージの影響を考慮しない)のひずみ工 ネルギー関数にダメージの影響を表現する関数を掛け合わ せることでダメージを受けた材料の接線剛性の寄与率を表 現した.

$$
\begin{aligned}
& W=W(\mathbf{C}, \Xi)=g(\Xi) W_{0}(\mathbf{C}) . \\
& \text { ここで, } \mathbf{C} \text { は右コーシーグリーンテンソル, }, \quad \Xi \text { ばメージ } \\
& \text { パラメータ, } g(\Xi) \in[0,1] \text { はダメージ関数, } W_{0}(\mathbf{C}) \text { は本来 } \\
& \text { のひずみエネルギー関数である. } \\
& \text { ひずみエネルギー関数を用いてグリーンラグランジェひ }
\end{aligned}
$$

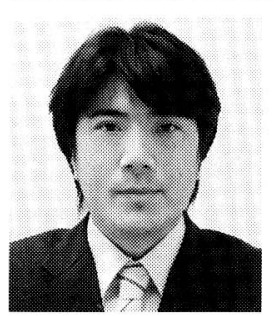

*2(侏)メカニカルデザイン（１82-0036 調布 市布田1-40-2アクシス調布 2 階) 構造解析 課. 1993 年, 熊本大学工学部機械工学科卒 業. 同年, 京七ラ侏入社, 1998年, 陎メカ ニカル・デザイン・アンド・アナリシス(現 メカニカルデザイン) 入社，現在に至る．専 門分野は非線形構造解析. 日本ゴム協会, 日本材料学会, 溶接学会, エレクトロニク 不実装学会会員. 
ずみ $\mathbf{E}$ と第 2 ピオラキルヒホッフ応力 $\mathbf{S}$ の関係は

$$
\mathbf{S}=\frac{\partial W}{\partial \mathbf{E}}=2 \frac{\partial W(\mathbf{C}, \Xi)}{\partial \mathbf{C}}=g(\Xi) \cdot 2 \frac{\partial W_{0}(\mathbf{C})}{\partial \mathbf{C}},
$$

であり，通常の応力にダメージ関数を乗じた値となる.

この定式化においてSimoはダメージの具体的な関数と して次を提唱した.

$$
\begin{aligned}
& \Xi=\max _{s \in(-\infty, t]} \sqrt{2 W_{0}(\mathbf{E}(s))}, \\
& g(x)=\beta+(1-\beta) \frac{1-\exp (-x / \alpha)}{x / \alpha} .
\end{aligned}
$$

式(3)中の $s \in(-\infty, t]$ で示されるようにダメージパラメー 夕は過去から現在までに受けた変形によるひずみエネルギ 一の最大值が取られる．そのパラメー夕を変数としてダメ ージ関数は指数関数を用いた式 (4) となる。ここで $\alpha$ は緩 和係数であり， $\beta$ は漸近值である．加えられた最大ひずみ が大きいほど，剛性低下も大きくなる

ひずみ空間でのダメージの判定は次式で行われる。

$$
\varphi(\mathbf{C}, \Xi)=\sqrt{2 W_{0}(\mathbf{E}(s))}-\Xi \leq 0 \text {. }
$$

Figure 1に示すように $\varphi(\mathbf{C}, \Xi)=0$ はダメージ曲面を表し， ダメージ曲面での法線ベクトル $\mathbf{N}=\frac{\partial \varphi(\mathbf{C}, \Xi)}{\partial \mathbf{C}}$ との関係か ら

$$
\varphi=0 \text { and }\left\{\begin{array}{l}
\mathbf{N}: \dot{\mathbf{E}}<0, \text { unloading(除荷) } \\
\mathbf{N}: \dot{\mathbf{E}}=0, \text { neutral (中立) } \\
\mathbf{N}: \dot{\mathbf{E}}>0, \text { loading (負荷) }
\end{array}\right.
$$

の判定式が得られる.

最終的にダメージを考慮した速度形式での応力とひずみ の関係は接線係数より

$$
\dot{\mathbf{S}}=\left\{\begin{array}{lc}
{\left[g(\Xi) \frac{\partial^{2} W_{0}}{\partial \mathbf{E}^{2}}+g^{\prime}(\Xi) \frac{\partial W_{0}}{\partial \mathbf{E}} \otimes \frac{\partial W_{0}}{\partial \mathbf{E}}\right]: \dot{\mathbf{E}},} & \text { if } \varphi=0 \text { and } \mathbf{N}: \dot{\mathbf{E}}>0 \\
g(\Xi) \frac{\partial^{2} W_{0}}{\partial \mathbf{E}^{2}}: \dot{\mathbf{E}}, & \text { otherwise }
\end{array},\right.
$$

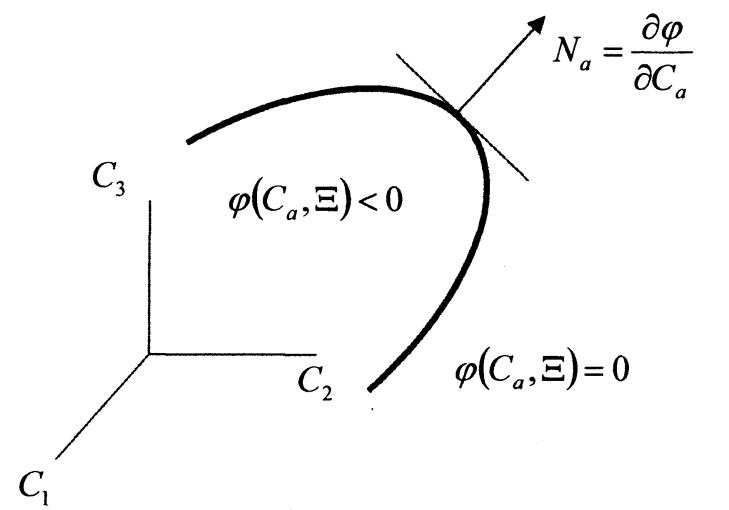

Figure 1 Damage surface on the principal strain space

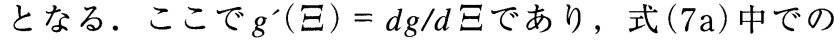
$\partial W_{0} / \partial \mathbf{E}$ つま今まで受けた応力の 2 乗にダメージ関数 の微分係数 $g^{\prime}(\Xi)$ を乗じた項が接線係数に加えられる.こ れは弾塑性計算に現れる塑性パラメータと同等の挙動を示 すので，負荷中に与えられるダメージの影響による剛性低 下を表現できる。しかしながらダメージを考慮しない本来 のひずみエネルギー関数を同定するのが困難であることが 弱点といえる.

\section{3. 不連続・連続ダメージモデル}

Miehe ${ }^{2)}$ は先のSimoによるダメージモデルを拡張し， これまでに受けた負荷の最大值 (不連続ダメージ) と履歴 (連続ダメージ)の二つのタイプに区別してダメージ関数を 表現した.

$$
\begin{aligned}
& \alpha(t)=\max _{s \in[0, t]} W(s), \quad \beta(t)=\int_{0}^{t}|\dot{W}(s)| d s, \quad(8 \mathrm{a}, \mathrm{b}) \\
& \hat{d}_{\alpha}(\alpha)=\stackrel{\infty}{d}_{\alpha}\left[1-\exp \left(-\frac{\alpha}{\eta_{\alpha}}\right)\right], \quad \hat{d}_{\beta}(\beta)=\stackrel{\infty}{d}_{\beta}\left[1-\exp \left(-\frac{\beta}{\eta_{\beta}}\right)\right],
\end{aligned}
$$

$$
d=\hat{d}_{\alpha}(\alpha)+\hat{d}_{\beta}(\beta)
$$

ここで $\alpha$ はSimoによる定義と同等で今までに受けた負荷 による最大のひずみエネルギー值をダメージパラメータと して扱われる. 一方 $\beta$ は追加項であり，除荷の最中にも積 算されるダメージパラメータとして扱われる。これらの二 つのパラメータからダメージ関数が定義され, Simoと同 様の数值計算処理がなされる， $\alpha$ は不連続ダメージ， $\beta$ は 連続ダメージとしての特徴をもつ. 追加された連続ダメー ジ関数を用いることで一定のひずみサイクルにおける摩耗 現象などのシミュレーションを行うことが可能となる．し かしながら, Simoのダメージモデルと同様に本来のひず みエネルギー関数を同定する作業が難しい. $\stackrel{\infty}{d}$ は最大のダ メージ率であり無次元数となる. $ク$ はダメージの飽和状態 を表す指標であり，応力と同じ次元となる。

Ogden体のひずみエネルギー関数 ${ }^{3)}$

$$
W=\sum_{n=1}^{3} \frac{\mu_{n}}{\alpha_{n}}\left[\left(\lambda_{1} \alpha_{n+\lambda_{2}} \alpha_{n+\lambda_{3}} \alpha_{n}\right)-3\right]
$$

において, 各定数を

$$
\begin{array}{lll}
\mu_{1}=0.62999, & \mu_{2}=1.193 \times 10^{-3}, & \mu_{3}=-1,00133 \times 10^{-2}, \\
\alpha_{1}=1.3, & \alpha_{2}=5.0, & \alpha_{3}=-2.0,
\end{array}
$$

とし，連続・不連続ダメージのパラメータには

$$
\stackrel{\infty}{d}_{\alpha}=\stackrel{\infty}{d}_{\beta}=0.4, \quad \eta_{\alpha}=\eta_{\beta}=4.0,
$$

を与え，純せん断試験を模擬した解析結果をFigure 2 に 示す．連続ダメージモデルでは除荷の過程および再負荷の 過程においてもダメージによる剛性低下の影響を見ること 


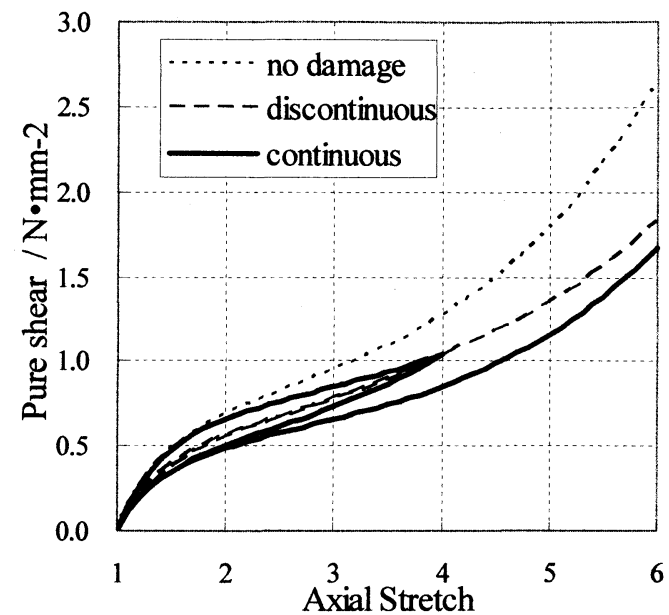

Figure 2 Pure shear test for Ogden material with damage. Comparison of continuous and discontinuous damage evolution. One solid line is continuous damage model, other dashed line is discontinuous damage model, the other doted line is no damage model.

ができる.

\section{Pseudo elastic modelによるダメージモデル}

一方, 別の概念によるゴムのダメージモデルの数式化が ある. 生体材料では超弾性体であるが, 負荷時と除荷時で 応力ひずみ挙動が異なる材料が多い。このヒステリシスを もつ材料モデルをダメージという概念はもたずに行きと帰 りで異なる構成則をもつモデルとして Fung) により提案 されたのがPseudo elastic modelである.

Ogden と Roxburgh' ${ }^{5)}$ がPseudo elastic modelの概念を 用いて考案したダメージモデルのひずみエネルギー関数を 以下に示す.

$$
\begin{aligned}
& W\left(\lambda_{1}, \lambda_{2}, \eta\right)=\eta \widetilde{W}\left(\lambda_{1}, \lambda_{2}\right)+\phi(\eta) \\
& \eta=1-\frac{1}{r} \operatorname{erf}\left[\frac{1}{m}\left(W_{m}-\widetilde{W}\left(\lambda_{1}, \lambda_{2}\right)\right)\right] \\
& \phi(\eta)=\int_{1}^{\eta} f(\eta) d \eta+(1-\eta) W_{m} .
\end{aligned}
$$

ここで, $\lambda_{1}, \lambda_{2}$ は主伸張比, $\widetilde{W}\left(\lambda_{1}, \lambda_{2}\right)$ は本来のひずみ エネルギー関数， $\eta$ はダメージパラメータ， $W_{m}$ はひずみ 履歴の最大値, $\phi(\eta)$ はダメージ関数, $r, m$ は材料定数と なる.

このモデルでは数值計算上, 負荷時において剛性低下を まねかないので，本来のひずみエネルギー関数の同定が通 常のカーブフィット等で簡単に得られる点が長所となる. 言い換えれば物理的にはダメージを受けているにせよ, 数 值計算的にはダメージレスのエネルギー関数を使用できる 点が長所となる. 無次元数 $r$ は初期のひずみエネルギー関 数に対する減少率であり, $m$ はひずみエネルギーと同じ単 位をもち，変形量に対するダメージの寄与率を表す。

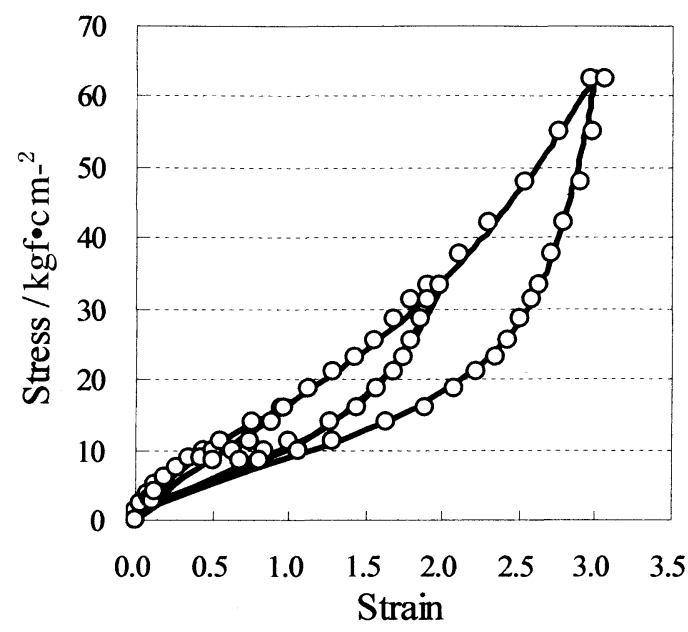

Figure 3 Mullins effect by Ogden \& Roxburgh model. Solid line is numerical results. Circle plots are experimental data obtained from Mullins \& Tobin(1957).

Mullins と Tobin $\left.{ }^{6}\right)$ が計測したデー夕に対して, 式(11) の Ogden体のひずみエネルギー関数において

$$
\begin{array}{ll}
\mu_{1}=8.00, & \mu_{2}=0.76, \quad \mu_{3}=-4.50, \\
\alpha_{1}=1.25, & \alpha_{2}=4.0, \quad \alpha_{3}=-2.0,
\end{array}
$$

とし, ダメージパラメータを $r=2.104, m=22.45$ の值を 用いて単軸引張状態で繰り返し負荷を与えた解析結果を Figure 3 に示す. 実測値に対して良好な数值解を得られて いる.

\section{5. 永久ひずみの取り扱い}

これまでに示したダメージモデルではダメージにより応 力ひずみ線図がヒステリシスを描く挙動(いわゆる理想的 な Mullins効果)をシミュレーションできる。しかしなが ら, 数学的には超弾性体と位置づけられるゴム材料に繰り 返し負荷を与えると, 物理的には永久ひずみを伴う挙動が 見られる. 事実Mullins と Tobinが計測したデー夕におい ても無視できない程度の永久ひずみが存在している．この 永久ひずみを有限要素法に組み込んだ例を以下に示す。

\section{1 伸張比に基づくモデル}

伸張比をパラメータとして永久ひずみを表現するために Holzapfel と Ogden ${ }^{7}$ は次の構成則を考案した.

$$
\begin{aligned}
& W\left(\lambda_{1}, \lambda_{2}, \lambda_{3}, \xi_{1}, \xi_{2}, \xi_{3}\right) \\
& =\widetilde{W}\left(\lambda_{1}, \lambda_{2}, \lambda_{3}\right)+\Omega\left(\lambda_{1}, \lambda_{2}, \lambda_{3}, \xi_{1}, \xi_{2}, \xi_{3}\right) .
\end{aligned}
$$

ここで， $\xi_{1}, \xi_{2}, \xi_{3}$ は主伸張比に対応するダメージ変 数であり, 関数 の追加関数である.それぞれ，

$$
\begin{aligned}
& \xi_{a}=\frac{1}{c}\left(\lambda_{a}-\bar{\lambda}_{a}\right), \\
& \Omega=\sum_{a=1}^{3}\left[\xi_{a}\left(\lambda_{a}-\bar{\lambda}_{a}\right)+\phi\left(\xi_{a}\right)\right],
\end{aligned}
$$




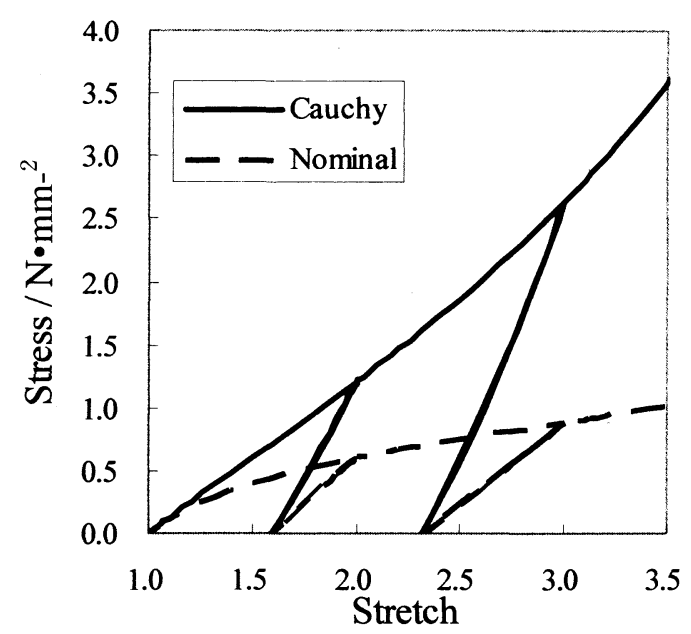

Figure 4 Simple tension loading/unloading curves. Solid line is Cauchy stress against the principle stretch, dashed line is nominal stress.

であり，矿はそれまでのひずみサイクルにおける各軸方 向での最大の主伸張比, $c$ は定数となる.

$\phi\left(\xi_{a}\right)$ はダメージ関数である.すなわち, 主軸方向の 最大伸張比に依存したダメージ変数を永久ひずみとして取 り扱っていることが理解できる.

式(11)の Ogden体のひずみエネルギー関数において $\mu_{1}=6.3 \times 10^{5}, \quad \mu_{2}=0.012 \times 10^{5}, \mu_{3}=-0.1 \times 10^{5}$,

$\alpha_{1}=1.3, \quad \alpha_{2}=5.0, \quad \alpha_{3}=-2.0$,

とし, ダメージパラメータを $\mathrm{C}=10^{-6}$ として, 単軸引張状 態で繰り返し負荷を与えた結果を Figure 4 に示す。除荷 後に大きな永久ひずみが残っていることが確認できる。こ のモデルでは応力軟化を考慮しないが，主軸方向の最大伸 張比に依存したダメージを永久ひずみとして取り扱うこと ができる.

\section{2 エネルギーに基づくモデル}

Dorfmann とOgden ${ }^{8)}$ は 4 章で示したPseudo elastic modelによるダメージモデルに追加のエネルギー関数を寄 与させることで応力軟化と永久ひずみの 2 つの挙動を同時 に表現した。

$$
\begin{aligned}
W & \left(\lambda_{1}, \lambda_{2}, \eta_{1}, \eta_{2}\right)=\eta_{1} \widetilde{W}\left(\lambda_{1}, \lambda_{2}\right) \\
& +\left(1-\eta_{2}\right) N\left(\lambda_{1}, \lambda_{2}\right)+\phi\left(\eta_{1}, \eta_{2}\right), \\
\eta_{1} & =1-\frac{1}{r} \tanh \left[\frac{W_{m}-\widetilde{W}\left(\lambda_{1}, \lambda_{2}\right)}{\mu m}\right], \\
\eta_{2} & =\tanh \left[\left(\frac{\widetilde{W}\left(\lambda_{1}, \lambda_{2}\right)}{W_{m}}\right)^{\alpha\left(W_{m}\right)}\right] / \tanh (1.0) .
\end{aligned}
$$

式(23)の $\eta_{1}$ は式(15) と等価であり, 応力軟化のダメージ パラメータを表す。一方, 新たに追加された式(24)の $\eta_{2}$ は永久ひずみのダメージパラメータであり，指数部は

$$
\alpha\left(W_{m}\right)=0.3+0.16 \frac{W_{m}}{\mu}
$$

る.ここで $\mu$ は初期のせん断剛性であり Ogden 体では

$$
\mu=\sum_{i=1}^{N} \mu_{i} \alpha_{i},
$$

で与えられる。

永久ひずみを表現するための追加関数 $N$ には Neo-Hooke 体のひずみエネルギー関数を修正した

$$
N\left(\lambda_{1}, \lambda_{2}, \lambda_{3}\right)=\frac{1}{2}\left[v_{1}\left(\lambda_{1}{ }^{2}-1\right)+v_{2}\left(\lambda_{2}{ }^{2}-1\right)+v_{3}\left(\lambda_{3}{ }^{2}-1\right)\right],
$$

が用いられる．単軸状態であれば

$$
N(\lambda)=\frac{1}{2}\left[v_{1}\left(\lambda^{2}-1\right)+\left(v_{2}+v_{3}\right)\left(\lambda^{-1}-1\right)\right],
$$

と簡略化でき, 各変数は

$$
\begin{aligned}
& v_{1}=0.4 \mu\left[1-\frac{1}{3.5} \tanh \left(\frac{\lambda_{m}-1}{0.1}\right)\right], \\
& v_{2}=v_{3}=0.4 \mu
\end{aligned}
$$

が用いられている．通常の Neo-Hooke体のひずみエネル ギー関数では $v_{1}=v_{2}=v_{3}$ となるが, 修正モデルでは軸方 向にのみ小さめのせん断剛性が取られることになる. 式 (29)にあるように軸方向のパラメータはそれまでのひずみ サイクルに扔ける最大伸張比に依存する。式 (11)の Ogden体のひずみエネルギー関数において

$$
\mu_{1}=-1.528380, \quad \mu_{2}=0.222564, \quad \mu_{3}=-1.13418 \times 10^{-3},
$$$$
\alpha_{1}=-1.011467, \quad \alpha_{2}=4.2047799, \quad \alpha_{3}=-4.398598, \quad(31)
$$

とし, 応力軟化のダメージパラメータを $r=1.25, m=$ 0.965 として, 単軸状態で繰り返し負荷を与えた解析結果 をFigure 5 に示す. 応力軟化と永久ひずみの 2 つの作用 を見ることができる.

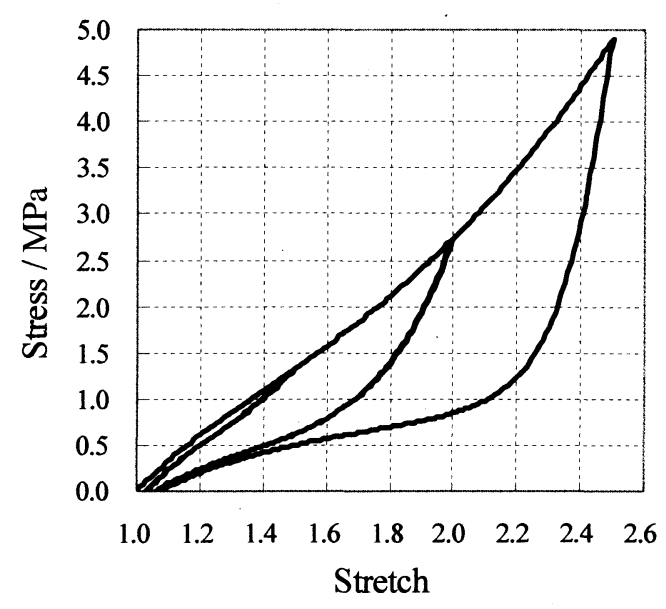

Figure 5 Numerical results of Permanent set and stress softening.

で与えられ，ひずみエネルギーの最大履歴に線形に依存す 


\section{6. ま め}

有限要素法でゴムのダメージモデルを取り扱う数值計算 手法を紹介した. Mullins効果を取り扱うにはOgdenス夕 イルのPseudo elastic model を使用すればダメージを受け ない本来のひずみエネルギー関数を同定することが簡易で ある.しかしながら，ダメージのクライテリアとしてスカ ラー量であるひずみエネルギーを用いているためダメージ の異方性を考慮することができない，例えば，最初にX 方向の負荷後に除荷し，その次にY方向に負荷するよう な場合を考えると，Y方向の負荷は一回目であるにも関わ らず，ダメージを受けた結果となる．このような異方性の 効果や大ひずみ粘弾性との組み合わせを考慮したモデルに ついてはヨーロッパを中心として盛んに研究されている.
また，現状の汎用有限要素法コードでは超弾性体に対す る永久ひずみの取り扱いが標準で用意されておらず，ユー ザーサブルーチンを駆使する必要がある，今後この領域に ついての整備も望まれる。

\section{References}

1) Simo, J.C.: Comput. Meth. Appl. Mech. Engrg., 60, 153 (1987)

2 ) Miehe, C.: Eur. J. Mech., A/Solids, 14, 697 (1995)

3 ) Ogden, R.W.: Proc. Roy. Soc. Lond. A, 326, 565 (1972)

4 ) Fung, Y.C.: "Biomechanics. Mechanical Properties of Living Tissues (2nd ed)", Springer-Verlag, NewYork. p.294 (1993)

5 ) Ogden, R.W., Roxburgh, D.G.: Proc. Roy. Soc. Lond. A, 455, 2861 (1999)

6 ) Mullins, L., Tobin, N.R.: Rubber Chem. Technol., 30, 555 (1957)

7 ) Holzapfel, G.A., Ogden, R.W., ECCMR. Proceedings of Constitutive Models for Rubber, p.189 (1999)

8 ) Dorfmann, A., Ogden, R.W.: Int. J. Solids Struct., 41, 1855 (2004)

\section{本会発行出版物ご案内}

\section{ゴム用 語 辞 典 B 6 版 400 頁 (1997.10発行) \\ 定価 4,725円（税込） 会員価格 送料 4,252 円 (税込) 450 円}

(ゴム産業に係わる技術用語，製品用語を幅広く収録したものです．収録用語約 4,500 語. $)$

* お申込の場合は, 必要事項(送付先住所, 勤務先, 氏名, 電話番号など)をご記入のうえ, FAXして下さい.

\section{社団法人 日本ゴム協会 図書係あて FAX 03 (3401) 4143}

